\title{
Cognitive Play Model of Narration "Quest» in Roald Dahl's Fairy Tale Charlie and the Chocolate Factory
}

\section{Когнітивна ігрова модель нарації «Квест» у казці Роалда Дала "Чарлі та шоколадна фабрика»}

Larysa Bieliekhova

Doctor in Philology, Professor

\section{Лариса Бслсхова}

доктор філологічних наук, професор

E-mail: lorabelehova@gmail.com orcid.org/0000-0002-1743-1865

\section{Alla Tsapiv}

Ph.D. in Philology, Associate

Professor, Postdoctoral student
Алла Цапів

кандидат філологічних наук, доцент, докторант

E-mail: alyatsapiv@i.ua orcid.org/0000-0002-5172-213X

Kherson State University

27, Universytetska Str., Kherson, Ukraine, 73000
Херсонський державний університет вул. Університетська, 27, м. Херсон, Україна, 73000

Original manuscript received September 01, 2018

Revised manuscript accepted March 13, 2019

\section{ABSTRACT}

The article focuses on reconstruction and analysis of the model of narration "Quest» in Roald Dahl's fairy tale Charlie and the Chocolate Factory. A narrative text is considered as a unit with semantic and communicative completeness. It is claimed 
that the elements of the narrative structure are narrator, narratee, the story (which includes the plot and its composition, fiction characters) and the model of narration. It is assumed that model of narration is a cognitive and linguistic construal, inbuilt into the narrative structure of the text. It is believed that play tenet forms the background of the model of narration of the fairy tale Charlie and the Chocolate Factory. The model of narration determines a definite plot and composition, a certain type of narrator and narratee. The semantics of search is realized in the plot - the search of the Golden ticket, the search of the secrets of the chocolate factory, overcoming the obstacles. Characters of the fairy tale are quest participants. Four of them personify simulacrums of modern society (Bodriyar) - greed and gluttony (Augustus Gloop), parent's permissiveness (Veruca Salt), uncontrolled TV watching (Mike Teavee), vanity (Violet Beauregarde). The fifth quest participant Charlie Bucket embodies modesty and honesty. The narrator of the fairy tale tells the story from the point of view a didactic adult, who criticizes pseudo values of the characters and supports honesty of the main hero Charlie. The narrator as if teaches the implied child reader through the questgame what is true and what is simulacrum. The winner of the quest becomes Charlie and other participants fail the quest because of their uncontrolled behavior.

Key words: narrative structure, model of narration, fairy tale, play tenet, narrator, narratee.

\section{Вступ}

Сучасна наратологія постає міждисциплінарною наукою, що поєднує теоретико-практичні здобутки літературознавства, лінгвістики, культурології, психології. Центром уваги науковцівнаратологів постають різні аспекти вивчення наративних текстів, зокрема лінгвостилістичні, когнітивні, психолінгвістичні, що уможливлює 3'ясування глибинної структури наративного тексту як результату лінгвокреативної діяльності митця (Ivashkevych, 2016; Beauvais, 2016; Fludernik, 2002; Изотова, 2015). Виникнення новітнього напряму дослідження художнього тексту в річищі психонаративу відкриває обрії для вивчення 'fictional minds' персонажів художнього твору, їх світогляду, внутрішнього світу, думок, емоцій, у які можна зазирнути, відчути, прочитати (Изотова, 2015; Шемуда, 2017), а відкриває доступ до них - наратор як оповідна інстанція художнього тексту (Palmer, 2004). I якщо першою площиною наративного тексту постає сама історія, яка стала основою сюжету художнього тексту, то другу площину формує дискурс наратора, який моделює наративний текст, маніпулює 
наративними одиницями, реалізує наративну стратегію художньої комунікації - 'наратор-нарататор'. Дослідження 3 психонаратології засвідчують, що у процесі прочитання та усвідомлення художнього тексту, а разом із тим i художньої дійсності (текстового світу), читач здатен задіяти ті самі когнітивні механізми, використати ті самі набуті знання, ерудицію, досвід, що й у реальному спілкуванні, у реальному житті (Margolin, 2009: 353; Ахутина, 2016). Для реалізації успішної художньої комунікації наратор так само має спиратись на життєвий досвід, знання, ерудованість потенційного адресата. У нашому дослідженні увагу зосереджено на казкових наративах, адресатом яких є дитина. Адресат-дитина має свої вікові, психологічні, емоційні особливості і саме тому наративні стратегії, які обирає наратор, мають перш за все враховувати специфіку дитячого світосприйняття. У контексті нашого дослідження вважаємо, що саме ігрове наративне моделювання художнього тексту забезпечує досягнення успішної художньої комунікації i викликає наративну допитливість дитини до прочитання казки та іiі емпатію як здатність усвідомлювати емоції персонажів та співчувати їм. У психолінгвістичному аспекті гра $є$ магістральною стратегією наративного моделювання художніх текстів для дітей i постає ключовим інструментом художньої комунікації між наратором та нарататором-дитиною.

Феномен гри $є$ предметом вивчення багатьох гуманітарних наук: філософії (Витгинштейн, 2005; Хинтикка 1980), психології (Выготский, 2004; Кравцов \& Кравцова, 2017; Миллер, 1999; Camerer, 2003; Garrod, 2002), літературознавства (Лотман, 1998; Славова, 2002), лінгвістики (Chrzanowska-Kluczewska, 2004; Старко, 2007). Гра та ігрова діяльність тлумачиться як спосіб пізнання навколишньої дійсності, як механізм соціалізації, формування типу поведінки в ігровому середовищі, основний принцип художньої комунікації між читачем та автором (Выготский, 2004; Лотман, 1998). Основою будь-якої гри є уява, фантазія, перевтілення, що також убачається головним для створення «художнього казкового світу» (Славова, 2002).

Філософське бачення гри сягає корінням концепції Канта про ігровий характер пізнавальних здібностей людини, про ігрову природу краси, а також естетичної концепції Шиллера, який визначав особливу роль гри у житті будь-якого індивіда. Науковці-філософи 
Г. Яусс, П. Ласкарис наголошують на естетичному значенні гри, iii впливі на естетичну поведінку - продуктивну, рецептивну, комунікативну. Гра сприяє стимуляції отримання радощів життя (Славова, 2002: 16-17), людина грає, оскільки їй цікаво жити, вона молода та палка і прагне насолоди. Гру пов'язують із творчістю та уявою, вона є одночасно їх проявом і засобом втілення.

Теорію «мовної гри» було розроблено австро-англійським філософом Л. Вітгенштейном у середині ХХ століття. У 1953 році в світ вийшла праця «Філософські дослідження», у якій науковець розробив власну теорію значення. Мовні ігри - це певна система комунікації. У такому сенсі саме поняття гри $\epsilon$ тотожним загальноприйнятому розумінню гри як явища. Дитина 3 кожним роком життя пізнає все більше інформації, назв предметів, загальної та спеціальної лексики. I чим більше дитина дізнається слів, тим більше вона буде «занурена» у мовну гру. Діти вивчають рідну мову за допомогою таких ігор, які Вітгенштейн називає розважальними. Мовна гра $є$ цільним утворення мови та дій, з якими вона пов'язана (Витгенштейн, 2005). Філософська теорія природи гри Вітгенштейна знайшла своє подальше віддзеркалення у лінгвістиці, зокрема у руслі лінгвокультурології, і засвідчила, що у розумінні гри різними мовними спільнотами домінують ментальні ознаки ігор, що відбивають їх сприйняття у певному лінгвокультурному соціумі i постають результатами рефлексії носіїв мови над конкретними ігровими ситуаціями (Старко, 2004: 11).

Фінський філософ Я. Хінтікка (1980), спираючись на ідеї «мовних ігор» Вітгенштейна, розробив теорію, яку назвав кванторні ігри «вивчення світу». За допомогою мовних ігор можна черпати інформацію про світ, яка закодована у першочерговому судженні, що у такому сенсі корелює із трансцендентальними теоріями Канта. Ходи гравця можна назвати термінами «пошук» та «знаходження»/«отримання». Існують умови, за яких можлива реалізація гри. По-перше, область пошуку має бути точно/ умовно визначеною; по-друге повинні існувати методи, які дозволяють встановити, коли дійсно знайдено об'єкт пошуку (Хинтикка, 1980: 259-260). Не менш важливим є усвідомлення виграшної стратегії гри або можливість вибору різних стратегій (Хинтикка, 1980: 273). Для нескінченної області гри існує безліч «чистих» стратегій які обирають гравці. Наявність гравця та його 
Cognitive Play Model of Narration "Quest» in Roald Dahl's Fairy...

супротивники передбачає реалізацію двох протилежних стратегій (стратегії-контрстратегії) (Кондаков, 1975: 592).

\section{Методи та методики дослідження}

У руслі вивчення гри як психологічного феномену зазначено, що в ігровій діяльності дітей реальні та казкові сюжети переплітаються, втім, різні за віком діти вкладають у цей сюжет різний зміст. Для дошкільників притаманним є повторювати дії, слова, рахівнички, пісні під час гри. Діти старші надають перевагу рольовим соціальним іграм, як от «у лікаря» або «у шофера» (Эльконин, 1999). За останнє десятиріччя усвідомлення значущості гри у житті та розвитку дитини еволюціонувало від суто дидактичного (діти грають самі і 3 власної ініціативи) до розуміння гри як форми пізнання світу. Під час гри під керівництвом дорослого дитина пізнає себе, робить перші кроки у формуванні стосунків 3 іншими, усвідомлює, моделює, скеровує власні дії та хід самої гри. Науковці виокремлюють такі найпопулярніші види ігор для дітей: ігридраматизації, будівельні ігри, дидактичні ігри та ігри за правилами (Кравцов \& Кравцова, 2017).

У літературознавстві принцип гри, ігрової діяльності тлумачиться як один 3 мотивів, що спонукає дитину до прочитання художнього твору. Літературна рецепція надає можливість дитині відчути себе у ролі персонажа твору, збагнути його, перевтілитись у нього, так само як і під час рольової гри - «приміряти» на себе іншу роль, зрозуміти як це і задовольнити свою допитливість. Ігрове ставлення дитини до дійсності детермінує іiі ігрове сприйняття літератури (Chrzanowska-Kluczewska, 2004).

Другий підхід літературознавців щодо взаємозв'язку гри 3 художнім твором - це вивчення гри 3 позиції іiі ролі у художній комунікації між автором та читачем. Гра проектується у текст та існує у межах тексту. Ігрове начало у художньому творі уможливлює «споглядання» як особливе бачення світу.

У такому сенсі гра усвідомлюється як певна система правил, яких дитина дотримується за власним бажанням в умовному середовищі i просторово-часових межах, натомість ігрове пов'язують як з поведінкою, так і навичками духу, з особливим 
Когнітивна ігрова модель нараиіï «Квест»у казиі Роалда Дала..

баченням реальності, незвичайним світосприйняттям (Gates, Steffel \& Molson, 2013).

Для художньої літератури для дітей ігрова стратегія видається найактуальнішою, автор обирає іiі як найбільш дотичну свідомості дитини. Гра $є$ ірраціональною, емоційно-імпульсивною. Гра $є$ однією 3 властивостей фантастичного як художнього явища, у грі уявне співіснує з реальним, іноді заміщує реальне і створює неможливе, несправжнє, «псевдореальність». Втім, дитина сприймає казкове/фантастичне у творі як первинне, істинне, справжне, на відміну від дорослого, який усвідомлює його вторинноумовний характер. Ігровий фантастичний світ має особливий естетичний вплив на читача, приносить здивування та напруження (Славова, 2002: 33).

У нашому дослідженні послуговуємось методом наратологічного аналізу, спрямованого на вивчення наративних одиниць художнього тексту (художнього наративу). Такими одиницями постають наратор (дорослий), нарататор (імпліцитний читач-дитина), подія, що $є$ основою сюжету, та модель нарації. Модель нарації забезпечує наративне аранжування всього казкового наративу. Спираючись на філософське і психологічне тлумачення гри, а також на вивчення ігрового принципу в художніх текстах для дітей 3 позиції літературознавства, вважаємо, що гра та ігрове начало - підгрунтя поетики наративу художніх текстів для дітей жанру казки. Гра $\epsilon$ основою казкового/фантастичного як художнього явища. Завдяки ігровому принципу дитина вбачає власну уяву у казці (Славова, 2002: 34). Гра постає засобом наратора регулювати емоції, світосприйняття, виховувати читачадитину через казковий наратив. Науковці зазначають «магічне» мислення та світосприйняття дитини, у них переважає ігрова рефлексія, анімізм, ірраціональне, «наївне» сприйняття художнього тексту - звідси така зацікавленість художньою фантазією. Казка як жанр дитячої літератури поєднує в собі елементи знайомого дитині навколишнього світу і світ фантазії. Читацький досвід дитини будується на казках. Фантастичне $є$ способом образного моделювання і будови «іншої дійсності», «паралельного всесвіту» свого роду «симулякру» дійсності. 


\section{Результати та дискусії}

Художній текст $є$ наративним за декількох умов. У наративному тексті є наратор як оповідна інстанція, що здійснює акт повістування; подія, тобто зміна вихідної ситуації - фізична або ментальна (Шмід, 2003), персонаж повинен бути антропоморфним або мати антропоморфні характеристики (анімалістичні, флористичні персонажі з антропоморфними властивостями тощо), часово-просторові межі повинні мати чіткі (або відносно чіткі) параметри (Fludernik, 2002). У контексті дослідження наративний текст розуміємо як певну структуру, що має семантичну, смислову та комунікативну цілісність. Одиницями наративної структури постають наратор, нарататор, подія/історія повістування та модель нарації. Модель нарації уможливлює маніпулювання одиницями наративу для створення наративного тексту. Модель нарації аранжує сюжетно-композиційні блоки художнього тексту, зумовлює актуалізацію певного типу наратора та нарататора. У дослідженні модель нарації тлумачимо як багатовимірний лінгвокогнітивний конструкт, який $є$ вписаним у наративну структуру художнього тексту. У контексті нашого дослідження вважаємо, що модель нарації художніх текстів для дітей базується на ігровому принципі. Гра $\epsilon$ змістовно-структурним компонентом художніх текстів для дітей. Ігровий принцип відповідає віковим особливостям та вимогам дитини або юнака, саме через гру відбувається ідейно-естетичний вплив на читача. Гра $є$ основою семантичної структури текстів для дітей (Лотман, 1998: 58). Поняттєва складова моделі нарації витлумачення iii імені в етимологічному та тлумачному словниках, з'ясування iї філософського розуміння. Так, квест є довгим та важким пошуком: quest is «a long or difficult search» (Oxford paperback dictionary Thesaurus, 2001: 727). Етимологічні розвідки засвідчують, що квестом є пошук для заволодіння чимось - to seek for to conquer (A short etymological dictionary of modern English, 1996: 2677). Квест є довгим та важким пошуком бажаного трофею.

Модель нарації «Квест» зумовлює певне сюжетно-композиційне аранжування казки. У сюжетно-композиційному блоці експозищіi наратор знайомить нас із персонажами - учасниками майбутнього квесту. Сюжетно-композиційний блок зав'язки містить завдання для 
пошуку - певний трофей (золотий квиток, магічний скарб тощо) та умови його виконання. У кульмінаційному моменті протагоніст опиняється перед вибором, вагається, знаходиться у зламній точці свого шляху. Розв'язка актуалізує результат пошуку та ілюструє зміни у житті героя після проходження всіх випробувань.

Квест відбувається серед учасників, які $€$ суперниками між собою та мають однакову мету. Серед учасників пошуку $\epsilon$ «справжні» герої та персонажі, у яких втілено симулякри сучасності (використовуємо термін слідом за Жаном Бодріяром), у яких втілено псевдоцінності певної культурно-історичної епохи (Бодріяр, 2004).

У казці Роалда Дала «Чарлі та Шоколадна фабрика» створено оповідну реальності 3 іï «псевдоцінностями» та «псевдоідеалами» сучасного світу - надмірна жадібність (Верука Солт), завелика любов до комп'ютерних ігор (Майк ТВ), обжерливість (Август Глуп), марнославство (Віолета Борегард) - втілюються у головних персонажах та викривають хибність таких вподобань, їх марність та погані наслідки. Симулякризована реальність описана у порівнянні із справжніми моральними та духовними цінностями, втіленням яких $\epsilon$ Чарлі Бакет, скромний, щирий, добрий та безкорисливий хлопчик.

Чарлі мешкає у дуже скромному будиночку на околиці міста із своєї дружньою родиною - двома бабусями, двома дідусями, мамою та татом. Бакети не можуть собі дозволити нічого окрім картоплі та капусти. I лише раз на рік у свій день народження Чарлі отримує найдорогоцінніший для нього подарунок - плитку шоколаду: «Only once a year, on his birthday, did Charlie Bucket ever get to taste a bit of chocolate.../... And each time he received it, on those marvelous birthday mornings, he would place it carefully in a small wooden box that he owned, and treasure it as though it were a bar of solid gold; and for the next few days, he would allow himself only to look at it, but never to touch it. Then at last, when he could stand it no longer, he would peel back a tiny bit of the paper wrapping at one corner to expose a tiny bit of chocolate, and then he would take a tiny nibblejust enough to allow the lovely sweet taste to spread out slowly over his tongue» (Dahl, 2013: 5). Складні полісиндетичні та асиндетичні конструкції уповільнюють розгортання подій, що $є$ дотичним дитячому передчуттю дива, коли дитина дуже чогось бажає i прагне зупинити момент. Алітерація звуку [s] має ономатопеічний характер, імітуючи заповітне шуршання обгортки, коли розгортаєш 
шоколадку і перебуваєш ці секунди у передчутті смакової насолоди. Повторення звуку [p], вимова якого потребує спершу затримання повітря, а потім його вивільнення, створює ефект затамування подиху дитини у передчутті чогось бажаного.

Надалі наратор веде оповідь від першої особи і звертається до читача: «But I haven't yet told you about the one awful thing that tortured little Charlie, the lover of chocolate, more than anything else. This thing, for him, was far, far worse than seeing slabs of chocolate in the shop windows or watching other children munching bars of creamy chocolate right in front of him. It was the most terrible torturing thing you could imagine, and it was this:

In the town itself, actually within sight of the house in which

Charlie lived, there was an ENORMOUS CHOCOLATE

FACTORY!» (Dahl, 2013: 6).

Капіталізація останніх слів графічно акцентує увагу на головній інтризі казки - місці, де буде проходити квест, місці, яке манить та чарує мешканців усього міста i особливо Чарлі. Таємничий Віллі Вонка - володар шоколадної фабрики оголошує про конкурс. Той, хто знайде у плитці шоколадки золотий квиток, матиме можливість відвідати його фабрику та побачити все на власні очі. Таких щасливчиків буде п’ятеро. Першим, хто знайшов золотий квиток на фабрику Віллі Вонки, був Август Глуп.

В образі Августа - втілено симулякр людини 3 надмірним апетитом, ненажерою, який не має ніяких інтересів у житті окрім іжі. Наратор зображує Августа використовуючи «дитячі» метафори та порівняння: he picture showed a nine-year-old boy who was so enormously fat he looked as though he had been blown up with a powerful pump. Great flabby folds of fat bulged out from every part of his body, and his face was like a monstrous ball of dough with two small greedy curranty eyes peering out upon the world (Dahl, 2013: 19). Тіло Августа наче надуто велетенською помпою, його обличчя нагадує потворну кульку 3 тіста 3 малесенькими смородинками очей. Читачу легко уявити зовнішність Августа, такі порівняння як тісто, надутий помпою, смородинки є зрозумілими дитині i одразу викликають асоціації - пухкенький, кругленький обжера. Мама Глупа додає: «Eating is his hobby, you know. That's all he's interested in». 
Дев’ятирічний Август є втіленням «псевдоцінностей» світу, жертвою переїдання та відсутності контролю з боку батьків. Їжа $є$ єдиним, що становить сенс його буття. В образі Августа - втілено симулякр надлишковості сучасного світу, надмірної реклами фастфуду, газованих напоїв, солодощів.

Другою володаркою щасливого квитка стала Верука Солт. Верука $є$ втіленням надмірної опіки своїх батьків, які балують доньку і виконують їі кожне бажання. Батько Веруки розповів журналістам про історію знаходження золотого квитка: «You see, boys», he had said, "as soon as my little girl told me that she simply had to have one of those Golden Tickets, I went out into the town and started buying up all the Wonka bars I could lay my hands on»"» (Dahl, 2013: 20). Верука заявила батьку, що мусить мати золотий квиток i той почав скуповувати батончики шоколаду тисячами, сотнями тисяч. За три дні квиток так і не знайшли, тому Верука все сумнішала і сумнішала, вона годинами лежала на підлозі, хвицяла ногами і жахливо вередувала: «I went home she would scream at me, "Where's my Golden Ticket! I want my Golden Ticket!» And she would lie for hours on the floor, kicking and yelling in the most disturbing way» (Dahl, 2013: 20). Зрештою, працівниця заводу тата знайшла для Веруки золотий квиток і в родині нарешті настав мир і спокій. Надмірність проявляється в усьому - у виконанні кожної забаганки доньки, у іï поведінці та ставленні до батьків. Верука є втіленням симулякру надмірного прагнення мати все, чого забажаєш. Батьки та суспільство створили Веруку, гроші батьків, пропозиція товарів та послуг - лише симулюють справжнє щастя.

Віолета Борегард - наступна володарка щасливого золотого квитка на шоколадну фабрику. Віолета прагне слави, популярності, бути у центрі спалахів камер. Втім, іiі досягнення дуже сумнівні. Віолета рекордсменка світу по довготривалому жуванні гумки. I та гумка, яку зараз жує дівчинка, і $є$ іiі головним скарбом. "I'm a gum chewer, normally», she shouted, «but when I heard about these ticket things of Mr. Wonka's, I gave up gum and started on chocolate bars in the hope of striking lucky. Now, of course, I'm back on gum. I just adore gum. I can't do without it...» (Dahl, 2013: 25). Верука не враховує думку своєї мами (And who's she to criticize) і щосили прагне найдовше всіх у світі жувати гумку. Дівчинка називає гумку своїм скарбом (treasured possession now), тим, що вона обожнює (I just 
adore gum), і тим, що надає ій відчуття повного комфорту (I simply wouldn't feel comfortable if I didn't have that little wedge of gum to chew on every moment of the day). Хибне відчуття слави, сумнівність досягнень і бажання хай там як потрапити у рекордсмени ще один симулякр сучасності. Діти вірять у псевдоідеали, обожнюють своїх кумирів, які з рештою нічого важливого не зробили, прагнуть бути абищо у центрі уваги папараці. Верука втілює ще один симулякр сучасності - марнославство.

Четвертим переможцем у пошуку квитка Віллі Вонки є Майк Тіві - обожнювач телебачення: "The nine-year-old boy was seated before an enormous television set, with his eyes glued to the screen» (Dahl, 2013: 26). Дев'ятирічний Майк дивиться фільми щодня, особливо йому подобаються фільми про гангстерів, постріли, зграї бандитів. Телевізійні гангстерські війни так вплинули на хлопця, що він і сам обвішався іграшковими пістолетами і раз у раз видавав 3 них черги пострілів: "and he was watching a film in which one bunch of gangsters was shooting up another bunch of gangsters with machine guns. Mike Teavee himself had no less than eighteen toy pistols of various sizes hanging from belts around his body, and every now and again he would leap up into the air and fire off half a dozen rounds from one or another of these weapons» (Dahl, 2013: 27). Майк втілює псевдоцінність сучасного людства - телебачення, яке заміщує хлопцю увесь світ, нав'язує смаки та манеру поведінки. Фільм і телебачення в цілому створюють для хлопця симулякр дійсності, адже весь його досвід та уява пов'язані із фільмами та серіалами, які Майк дивиться на величезному екрані. Майка дратує найменше втручання зовнішнього світу, він був дуже злим, коли репортери прийшли взяти в нього інтерв'ю та зробити кілька знімків.

Чарлі був п'ятим щасливим володарем плитки із золотим квитком. Як у казці, магічна плитка номер три містила бажаний трофей. Саме тоді, коли Чарлі втратив надію, оскільки ані у плитці, яку він отримав на день народження, ані у шоколадці, яку йому подарував дідусь, не було квитка. Чарлі знайшов у снігу монетку, на яку купив у найближчій крамниці шоколадку Віллі Вонки i знайшов під обгорткою той самий п'ятий золотий квиток.

Той золотий квиток, який кожен учасник квесту знайшов у плитці шоколаду, містив завдання та умови пошуку: I, Willy Wonka, have decided to allow five children to visit my factory this year. So 
watch out for the Golden Tickets! ...And the five lucky finders of these five Golden Tickets are the only ones who will be allowed to visit my factory and see what it's like now inside! Good luck to you all, and happy hunting! (Signed Willy Wonka) (Dahl, 2013: 40). Пошук чарівного квитка позиціонується як полювання, а того, хто його знайде, чекатиме наступний етап квесту на шоколадній фабриці. Потрапивши на шоколаду фабрику учасникам квесту розкриються всі таємниці створення шоколаду, усі дива та магія (These lucky five will be shown around personally by me, and they will be allowed to see all the secrets and the magic of my factory) (Dahl, 2013: 40). Крім того, проходження квесту передбачає отримання нагороди. Переможцю подарують шоколаду стільки, скільки він зможе їсти упродовж всього свого життя (Then, at the end of the tour, as a special present, all of them will be given enough chocolates and sweets to last them for the rest of their lives!) (Dahl, 2013: 40).

Усі п'ятеро учасників квесту разом із своїми дорослими помічниками (батьками, дідусем) вирушають до шоколадної фабрики на пошуки таємниць та пригод. Квест як гра передбачає поступове виконання завдань і проходження випробувань на різних етапах пошуку. Той учасник, що пройшов етап квесту, потрапляє до наступного.

У казці Роалда Дала дидактична функція розкривається у наративних ситуаціях, в яких персонажі, що втілюють симулякри дійсності, сходять 3 дистанції i припиняють пошук секретів шоколаду саме через свої псевдоцінності та марнославство.

Август Глуп не зміг втриматись від спокуси попити шоколаду із шоколадної річки. Хлопець, незважаючи на заборону, нахилився так низько до річки, що його затягнуло в одну із звисаючих над річкою великих труб.

Віолета Борегард, яка невпинно жувала гумку для встановлення сумнівного рекорду, припинила змагання саме із-за свого нестримного бажання скуштувати нову гумку, що виробив Віллі Вонка. Сам Вонка назвав таку гумку найвидатнішим i найгеніальнішим винаходом. Гумка створена для заміни повноцінного сніданку, обіду та вечері, адже вона може замінити будь-який смак їжі і надати відчуття смакової насолоди та ситості: «my latest, my greatest, my most fascinating invention! It's a chewing- 
gum meal! It's . . it's . . it's . . That tiny little strip of gum lying there is a whole three-course dinner all by itself!» (Dahl, 2013: 73). Верука схопила гумку, почала жувати і перетворилась на гігантський шар чорничного кольору (десертом гумки був чорничний пиріг).

Верука Солт поплатилась за своє неконтрольоване бажання отримувати найдрібнішу забаганку. Верука побачила в одній з кімнат фабрики білочок, що лущать горіхи, і забажала будь-що мати таку саму білку в себе. Віллі Вонка заборонив заходити до приміщення з білками, та Верука не звикла до відмов. Дівчинка схопила білку, втім iii прийняли за зіпсований горіх і викинули у сміттєпровід.

Четвертий учасник квесту Майк Тіві постраждав через свою безмежну любов до телевізору. Він захотів повторити трюк 3 шоколадкою, яку Віллі Вонка передав через телевізор. Майку не було дозволено робити експеримент, втім його бажання бути першим хлопцем, якого передали через телевізор, було настільки сильним, що він стрибнув у екран і перетворився на крихітного хлопчика. Батьки були приголомшені теперішніми розмірами власного сина, втім нічого не могли вдіяти.

Усі випробування квесту пройшов тільки Чарлі. Він не прагнув недозволеного, не намагався стати сенсацією, з'їсти тони шоколаду або скуштувати незвичайні солодощі. Саме скромність, слухняність та покірливість Чарлі сприяли його перемозі. У винагороду за подолання усіх перешкод, за щире серце хлопця, Віллі Вонка вирішив подарувати йому свою Шоколадну фабрику: «You see, my dear boy, I have decided to make you a present of the whole place. As soon as you are old enough to run it, the entire factory will become yours» (Dahl, 2013: 115) та забрати усіх родичів Чарлі теж до фабрики, щоб родина допомагала хлопцю нею керувати.

Віковий критерій $\epsilon$ визначальним у створенні літератури для дітей (Славова, 2002; Beauvais, 2015 та ін.), вік потенційного читача сприяє моделюванню особливого виду естетичної художньої комунікації «автор (доросла людина) - читач (дитина/юнак)». У казці позиція дитини (імпліцитного нарататора) реалізується через «рольові ігри автора». Думка дорослого віддзеркалюється через використання дитячого досвіду і створення художніх образів, що грунтуються на уявленнях письменника про дитяче світобачення (Славова, 2002: 10). Автор казки втілює свої ідеї через «дитячий код». 
У такий спосіб дитина стає співавтором художнього твору i $\epsilon$ вирішальною у виборі наративних стратегій. Гетеродієгетичний наратор (Женетт, 1998) історії про Чарлі веде оповідь як спостерігач подій, що знає думки персонажів, майбутній хід подій та робить власні коментарі 3 приводу поведінки та характеру учасників квесту. Наратор виконує роль дорослого, що направляє, критикує, засуджує та схвалює. Наратор робить досить різкі коментарі щодо поведінки та способу життя персонажів AUGUSTUS GLOOP, а greedy boy (Август є жадібним хлопцем); VERUCA SALT, a girl who is spoiled by her parents (Верука - зіпсоване дівчисько, розбалувана батьками); VIOLET BEAUREGARDE, a girl who chews gum all day long (Віолета весь час тільки і робить, що жує гумку); MIKE TEAVEE, a boy who does nothing but watch television (Майк нічого не робить окрім перегляду телевізору); CHARLIE BUCKET, the hero (Чарлі - це герой казки). Наратор висловлює свою чітку позицію щодо кожного з учасників квесту і тільки Чарлі з позиції наратора $\epsilon$ героєм казки. В його описі відсутні будь-які негативні коментарі.

У такий спосіб наратор через гру - моральний, дидактичний квест, реалізує художню комунікацію із читачем. Гра тут постає свого роду способом моделювання реальної ситуації, проектуванням реальних елементів, складових, сценаріїв у віртуально-умовне середовище. Гра-квест уможливила моделювання дійсності, стала засобом оволодіння для читача різними типами поведінки у певних життєвих ситуаціях. Таке моделювання ситуації дало змогу непідготовленій/недосвідченій дитині в ігровій формі уявити себе у новій іпостасі за незвичних умов, відчути себе у новій ролі та випробувати ту чи ту модель поведінки. Будь-яка гра завжди відбувається за правилами, дотримання яких є обов'язковим. Гра має набір учасників або певні ролі, сценарій дій. Втім, у грі, на відміну від дійсності, можна зупинити час, змінити тактику, умовно перемогти непереможне та дістати недосяжне. Це засвідчує іiі магічну значущість, важливість психологічного впливу та виховну цінність. Гра допомагає здолати страх перед невідомим і формує необхідну емоційну стійкість у разі виникнення вже змодельованої ситуації у реальному житті. Мистецтво гри у іï двоплановості «серйозному» та одночасно «умовному» типі поведінки. Учасник гри одночасно сприймає іiі умовність (усвідомлює, що перед ним, 
наприклад, не живі, а іграшкові тварини) та одночасно забуває про нереальність того, що відбувається і уявляє все насправді. При цьому емоції та відчуття, які викликають учасники гри у реальному житті, залишаються такими ж самим і в умовно-ігровій ситуації. Психологічна потреба у грі є природною для людини, іiі втілення у будь-яких ситуаціях супроводжує життя людини на всіх стадіях іiі розвитку (Chrzanowska-Kluczewska, 2004).

\section{Висновки}

Модель нарації «Квест» задає аранжування кожної одиниці наративної структури художнього тексту - наратор (гетеродієгетичний всезнаючий дорослий, що регулює та повчає), нарататор (імпліцитний читач, для якого створено казку, враховано його вікові та психологічні особливості) та сама історія про Чарлі, що має дидактичну спрямованість, містить фантастичний сюжет, чарівні трансформації, заплутаність, випробування та перемогу. Персонажі казки є суперниками квесту, пройти всі перешкоди i здобути перемогу може тільки один. У персонажах казки втілено симулякри сучасної дійсності, що протиставляються щирості та справжності головного героя - Чарлі Бакета. Модель нарації «Квест» у казці «Чарлі та шоколадна фабрика» зазнає специфікації і постає моральним пошуком. Гетеродієгетичний наратор казки у ролі дорослого здійснює коментарі дидактичного плану впродовж всієї оповіді. Наратор засуджує захопленням псевдоідеалами персонажів та схвалює чесність головного героя Чарлі. Наратор повчає через гру-квест що $є$ істинним, а що хибним, симулякром. Наратор казки постає суто текстовою категорією, що за допомогою дискурсу здійснює вплив на читача-дитину. Магістральна роль наратора - через маніпулювання наративними одиницями у тексті здійснювати художню комунікацію із адресатом художнього тексту. Наратор моделює нарацію у такий спосіб, щоб у ігровому форматі передати необхідні знання, навчити, виховати, зацікавити дитинучитача. Модель реальної ігрової комунікації накладається на наративне ігрове аранжування художнього тексту і постає потужним когнітивно-наративним інструментом регулювання дитячої поведінки та світогляду. 


\section{Література}

Ахутина Т. Смысл, смысловое поле и модель ситуации текста. Психолингвистика. 2016. Вип. 20(1). С. 15-25.

Бодріяр Ж. Симулякри і симуляція / пер. 3 франц. В. Ховхун. Київ: Вид-во Соломії Павличко «Основи», 2004. 230 с.

Витгенштейн Л. Избранные труды / пер. с нем. и англ. В. Руднева. Москва: Издательский дом «Территория будущего», 2005. 440 с.

Выготский Л.М. Психология развития ребенка. Москва: Смысл; Эксмо, 2004. 12с. Женетт Ж. Фигуры / пер. с фр. С. Зенкина. Москва: Изд-во Сабашниковых, 1998. C. $60-281$.

Изотова Н.П. Лингвистика психонарратива в романах Дж.М. Кутзее: параметры изучения. Science and Education a New Dimension. Philology, III(9), Issue 44, 2015. С. 45-49.

Кодаков Н.И. Логический словарь-справочник. Москва: Изд-во «Наука», 1975. $721 \mathrm{c.}$

Кравцов Г.Г., Кравцова Е.Е. Психология игры. Москва: «Левъ», 2017. 184 с.

Лотман Ю.М. Структура художественного текста. Санкт-Петербург: «Искусство СПБ», 1998. 285 с.

Миллер С. Психология игры. Санкт-Петербург: Университетская книга, 1999. 320 с.

Славова М.Т. Волшебное зеркало детства. Статьи о детской литературе. Киев: Издательско-полиграфический центр «Киевский университет», 2002. 94 с.

Хинтикка Я. Логико-эпистемологические исследования / пер. с англ. В.Н. Брюшинкина, Э.Л. Наппельбаума, А.Л. Никифорова. Москва: «Прогресс», 1980. 448 с.

Шемуда М. Особливості репрезентації емоційності в казці Л. Керрола «Аліса в Країні чудес». Психолінгвістика. 2017. Вип. 22(2). С. 127-137. doi. org/10.5281/zenodo.1069554

Шмид В. Нарратология. Москва: Языки славянской культуры, 2003. 312 с.

Старко В.Ф. Концепт ГРА в контексті слов'янських і германських культур (на матеріалі української, російської, англійської та німецької мов): автореф. дис. ... канд. філол. наук: 10.02.15. Київ, 2004. 15 с.

Старко В.Ф. Концепт «гра»: монографія. Луцьк: Вежа, 2007. 204 с.

Эльконин Д. Психология игры. Москва: Владос, 1999. 360 с.

A Short Etymological Dictionary of Modern English. (1996). L.; N.Y.: Routledge.

Beauvais, C. (2015). The Mighty Child. Time and Power in Children's Literature. Amsterdam: John Benjamins.

Camerer, C. (2003). Behavioral Game Theory: Experiments in Strategic Interaction. N.Y.: Russel Sage Foundation.

Chrzanowska-Kluczewska, E. (2004). Language games: pro and against. TAiWPN Universitas Kraków: Universitas.

Fludernik, M. (2002). Towards a 'natural' narratology. London and New York: Rouledge. Taylor and Francis group.

Garrod, S. (2002). The challenge of dialogue for theories of language processing. In G.T.M. Altman (Ed.), Psycholinguistics: Critical Concepts in Psychology (Vols. 3), (pp. 464-488). L.; N.Y.: Routledge.

Gates, P.S., Steffel, S.B., \& Molson, F.J. (2013). Fantasy literature for children and young adults. Lanham, Maryland, and Oxford: The Scarecrow press Inc. 
Ivashkevych, E.E. (2016). Psycholinguistic aspects of narrative discourse. Psycholinguistics, 20(1), 87-97.

Margolin, U. (2009). Narrator. In F. Jannidis, M. Martınez, J. Pier \& W. Schmid (Eds.), Handbook of Narratology (pp. 351-365). Berlin; N.Y.: Walter de Gruyter. Oxford Paperback Dictionary Thesaurus. (2001). N.Y.: Oxford University Press.

Palmer, A. (2004). Fictional minds. Lincoln and London: University of Nebraska Press.

\section{Джерела}

Dahl, R. (2013). Charlie and the Chocolate Factory. London: Puffin.

\section{References}

Akhutina, T. (2016). Smysl, smyslovoya pole i model situatsii teksta [Meaning, semantic field and the model of text situation]. Psykholinhvistyka Psycholinguistics, 20(1), 15-25 [in Russian].

Bodriyar, Zh. (2004). Simulyakry $i$ simulyatsiya [Simulacrum and simulation]. (V. Hovhun, Trans). Kyiv: Osnovy [in Ukrainian].

Wittgenstein, L. (2005). Izbrannye Trudy [Selected Papers]. (V. Rudneva, Trans). Moscow: Territoriya Buduschego [in Russian].

Vygotsky, L.M. (2004). Psihologiya Razvitiya Rebenka [The Psychology of a Child's Development]. Moscow: Smysl; Eksmo [in Russian].

Genette, G. (1998). Figury [Figures]. (S. Zenkin, Trans). Moscow: Izd-vo im. Sabashnikovyh [in Russian].

Izotova, N.P. (2015). Lingvistika psihonarrativa v romanah Dzh.M. Kutzee: paranetry izucheniya [Linguistics of psychonarration in J.M. Coetzee's novels: aspects of study]. Science and Education a New Dimension. Philology, III(9), Issue 44, 4549 [in Russian].

Kodakov, N.I. (1975). Logicheskij Slovar-Spravochnik [Logical thesaurus]. Moscow: Izd-vo «Nauka» [in Russian].

Kravtsov, G.G., \& Kravtsova, E.E. (2017). Psihologiya igry [Psychology of the game]. Moscow: 'Lev' [in Russian].

Lotman, Yu.M. (1998). Structura Hudozhestvennogo Teksta [The Structure of the Literary Text]. Saint Petersburg: Iskusstvo-SPB [in Russian].

Miller, S. (1999). Psihologiia Igry [Psychology of the Game]. Saint Petersburg: Universitetskaya Kniga [in Russian].

Slavova, M.T. (2002). Volshebnoye Zerkalo Detstva. Statji o Detskoj Literature [Magic Mirror of Childhood: Articles on Children's Literature]. Kyiv: «Kyivskyi Universytet» [in Russian].

Hintikka, Ja. (1980). Logico-epistemologicheskiye Issledovaniya [The Logic of Epistemology and the Epistemology of Logic]. (V.N. Bryushinkina, E.L. Nappelbauma, A.L. Nikifirova, Trans). Moscow: Progress [in Russian].

Shemuda, M. (2017). Osoblyvosti Reprezentatsii Emotsiinosti v Kaztsi L. Carrola «Alice's Adventures in Wonderland» [Features of the Emotionality's Representation in the tale by L. Carroll «Alice's Adventures in Wonderland»]. Psykholinhvistyka - Psycholinguistics, 22(2), 127-137. https://doi.org/10.5281/ zenodo.1069554 [in Ukrainian]. 
Когнітивна ігрова модель нараиіï «Квест»у казиі Роалда Дала...

Schmid, W. (2003). Narratologiya [Narratology]. Moscow: Yazyki Slavyanskoi Kultury [in Russian].

Starko, V.F. (2004). Kontsept 'GRA' v konteksti slovianskyh i germanskyh kultur (na materiali ukrainskoi, rosiiskoi, angliiskoi ta nimetskoi mov) [The Concept GAME in the Context of Slavic and Germanic Cultures (in Ukrainian, Russian, German and English languages)]. Extended abstract of candidate's thesis. Kyiv [in Ukrainian].

Starko, V.F. (2007). Kontsept 'Gra' [Concept 'Game']. Lutsk: Vezha [in Ukrainian].

Elkonin, D. (1999). Psihologiya igry [Psychology of the Game]. Moscow: Vlados [in Russian].

A Short Etymological Dictionary of Modern English. (1996). L.; N.Y.: Routledge.

Beauvais, C. (2015). The Mighty Child. Time and Power in Children's Literature. Amsterdam: John Benjamins.

Camerer, C. (2003). Behavioral Game Theory: Experiments in Strategic Interaction. N.Y.: Russel Sage Foundation.

Chrzanowska-Kluczewska, E. (2004). Language games: pro and against. TAiWPN Universitas Kraków: Universitas.

Fludernik, M. (2002). Towards a 'natural' narratology. London and New York: Rouledge. Taylor and Francis group.

Garrod, S. (2002). The challenge of dialogue for theories of language processing. In G.T.M. Altman (Ed.), Psycholinguistics: Critical Concepts in Psychology (Vols. 3), (pp. 464-488). L.; N.Y.: Routledge.

Gates, P.S., Steffel, S.B., \& Molson, F.J. (2013). Fantasy literature for children and young adults. Lanham, Maryland, and Oxford: The Scarecrow press Inc.

Ivashkevych, E.E. (2016). Psycholinguistic aspects of narrative discourse. Psycholinguistics, 20(1), 87-97.

Margolin, U. (2009). Narrator. In F. Jannidis, M. Martınez, J. Pier \& W. Schmid (Eds.), Handbook of Narratology (pp. 351-365). Berlin; N.Y.: Walter de Gruyter. Oxford Paperback Dictionary Thesaurus. (2001). N.Y.: Oxford University Press.

Palmer, A. (2004). Fictional minds. Lincoln and London: University of Nebraska Press.

\title{
Sources
}

Dahl, R. (2013). Charlie and the Chocolate Factory. London: Puffin.

\begin{abstract}
АНОТАЦІЯ
Статтю присвячено реконструкції та аналізу моделі нарації "Квест» у казці Роалда Дала "Чарлі та шоколадна фабрика». Наративний текст характеризується комунікативною та семантичною цілісністю. У наративному тексті наявні такі складники: наратор як оповідна інстанція; подія, тобто зміна вихідної ситуації - фізична або ментальна; персонаж наративного тексту облігаторно є антропоморфним або має антропоморфні характеристики; часово-просторові межі повинні мати чіткі (або відносно чіткі) параметри. Елементами наративної структури художнього тексту постають наратор, нарататор, історія (що вміщує сюжет, композиційне аранжування,
\end{abstract}


художніх персонажів) та модель нарачії. Модель нарації витлумачено як лінгвокогнітивний конструкт, який $\epsilon$ вписаним у наративну структуру художнього тексту. З'ясовано, що модель нарації казки “Чарлі та шоколадна фрабрика» у своєму підгрунті побудована на ігровому принципі. Модель нарації «Квест» зумовлює реалізацію певного сюжету, композиційного аранжування, типу наратора та нарататора. Семантика пошуку (квесту) реалізована у сюжеті казки - пошук Золотого квитка, пошук секретів шоколадної фабрики, подолання перешкод. Персонажі казки постають учасниками квесту. У чотирьох персонажах втілено симулякри сучасної дійсності (термін Жана Бодріяра) жадібність та обжерство (Август Глуп), батьківська вседозволеність (Верука Солт), безконтрольний перегляд телевізора (Майк Тіві), марнославство (Віолета Борегард). П'ятий учасник квесту Чарлі Бакет втілює скромність $i$ чесність. Наратором казки є гетеродієгетичний оповідач (термін Женетта), що постає у ролі дорослого з дидактичними коментарями. Наратор засуджує захопленням псевдоцінностями персонажів та заохочує чесність головного героя Чарлі. Наратор ніби повчає через гру-квест що є істинним, а що хибним, симулякром. Переможцем квесту стає Чарлі, натомість інші учасники не здолали випробування через свою неконтрольовану поведінку.

Ключові слова: наративна структура, модель нарації, казка, ігровий принцип, наратор, нарататор.

\title{
Белехова Лариса, Цапив Алла. Когнитивная игровая модель наррации "Квест» в сказке Роалда Дала "Чарли и шоколадная фабрика»
}

\begin{abstract}
АННОТАЦИЯ
Статья посвящена реконструкции и описанию модели наррации «Квест» в сказке Роалда Дала "Чарли и шоколадная фрабрика». В исследовании нарративный текст понимаем как коммуникативную и семантическую целостность. Элементами нарративной структуры текста являются нарратор, наррататор, история (сюжет, композиционная аранжировка, художественные персонажи) и модель наррации. Модель наррации трактуем как лингвокогнитивный конструкт, вписанный в нарративную структуру художественного текста. В исследовании установлено, что модель наррации сказки "Чарли и шоколадная фабрика» построена на игровом принципе. Семантика поиска (квеста) реализована в сюжете сказки - поиск Золотого билета, поиск секретов шоколадной фабрики, преодоление преград. Персонажи сказки являются участниками квеста. В четырех персонажах воплощены симулякры современной действительности (мы используем термин Жана Бодрияра) - жадность и обжорство (Август Глуп), родительская вседозволенность (Верука Солт), бесконтрольный просмотр телевизора (Майк ТиВи), тщеславие (Виолета Борегард). Пятый участник квеста Чарли Бакет воплощает скромность и честность. Гетеродиегетический нарратор сказки выполняет роль взрослого наставника, который делает дидактические и
\end{abstract}


Когнітивна ігрова модель нараиіï «Квест»у казиі Роалда Дала...

поучительные комментарии. Магистральная роль наратора - манипулируя нарративными единицами, реализовать успешную художественную коммуникацию с читателем-ребенком. Нарратор моделирует наррацию таким способом, который позволит в игровой форме передать необходимые знания, научить, воспитать, заинтересовать читателя-ребенка. Модель реальной игровой коммуникации наслаивается на когнитивную нарративную игровую модель художественного текста и таким образом создает когнитивнонарративный инструмент, позволяющий регулировать детское поведение и мировосприятие.

Ключевые слова: нарративная структура, модель наррации, сказка, игровой принцип, нарратор, наррататор. 